\title{
Zooplankton community resilience and aquatic environmental stability on aquaculture practices: a study using net cages
}

\author{
Dias, JD. *, Simões, NR. and Bonecker, CC. \\ Programa de Pós-Graduação em Ecologia de Ambientes Aquáticos Continentais, Departamento de Biologia, Núcleo de \\ Pesquisas em Limnologia, Ictiologia e Aquicultura - Nupélia, Universidade Estadual de Maringá - UEM, Av. Colombo, \\ 5790, CEP 87020-900, Maringá, PR, Brazil \\ *e-mail: julianadeo@hotmail.com
}

Received September 28, 2010 - Accepted February 8, 2011 - Distributed February 29, 2012

(With 4 figures)

\begin{abstract}
Fish farming in net cages causes changes in environmental conditions. We evaluated the resilience of zooplankton concerning this activity in Rosana Reservoir (Paranapanema River, PR-SP). Samples were taken near the net cages installed at distances upstream and downstream, before and after net cage installation. The resilience was estimated by the decrease in the groups' abundance after installing the net cages. The zooplankton community was represented by 106 species. The most abundant species were Synchaeta pectinata, S. oblonga, Conochilus coenobasis, Polyarthra dolichoptera and C. unicornis (Rotifera), Ceriodaphnia cornuta, Moina minuta, Bosmina hagmanni and C. silvestrii (Cladocera) and Notodiaptomus amazonicus (Copepoda). The resilience of microcrustaceans was affected in the growing points as this activity left the production environment for longer, delaying the natural ability of community responses. Microcrustaceans groups, mainly calanoid and cyclopoid copepods, had a different return rate. The net cage installation acted as a stress factor on the zooplankton community. Management strategies that cause fewer risks to the organisms and maximize energy flow may help in maintaining system stability.
\end{abstract}

Keywords: anthropogenic disturbance, environmental impact, reservoir, fish-culture and plankton.

\section{Resiliência da comunidade zooplanctônica na aquicultura: um estudo em tanques rede}

\section{Resumo}

A piscicultura em tanques rede causa mudanças nas condições ambientais. Este estudo avaliou a resiliência do zooplâncton em áreas de cultivo de peixes no reservatório de Rosana (rio Paranapanema, PR-SP). As coletas foram realizadas próximo aos tanques rede, e, a montante e a jusante deles, antes e após a instalação dos tanques. A resiliência foi estimada utilizando a diminuição na abundância dos grupos após a instalação dos tanques. A comunidade zooplanctônica foi representada por 106 espécies. As espécies mais abundantes foram Synchaeta pectinata, S. oblonga, Conochilus coenobasis, Polyarthra dolichoptera e C. unicornis (Rotifera), Ceriodaphnia cornuta, Moina minuta, Bosmina hagmanni e C. silvestrii (Cladocera) e Notodiaptomus amazonicus (Copepoda). A resiliência dos microcrustáceos foi afetada nos pontos de cultivo, pois, esta atividade deixou o ambiente produtivo por mais tempo, atrasando a capacidade natural das respostas da comunidade. Os microcrustáceos, principalmente copépodes calanoides e ciclopoides tiveram diferentes taxas de retorno. A instalação dos tanques rede agiu como um fator de estresse sobre a comunidade zooplanctônica. Estratégias de gestão que causam menos riscos para os organismos e maximizam o fluxo de energia podem ajudar na manutenção da estabilidade do sistema.

Palavras-chave: distúrbio antropogênico, impacto ambiental, reservatório, cultivo de peixe e plâncton. 


\section{Introduction}

Fish farming in net cages is an increasingly popular practice (Alves and Baccarin, 2005) due to the chance of increasing fish productivity where conventional fish farming (excavated ponds) is not possible (Schmittou, 1993). In Brazil, the government encourages net cage fish culture in public waters, and this was one of objectives of the fisheries management agency (Ministério da Pesca e Aquicultura do Brasil). The inclusion of this activity, as well as the multiple uses of water, should be appropriately monitored and managed to avoid possible problems related to environmental degradation, since the need to supply the population growth and industrial and agricultural demand have created permanent pressure on surface water resources (Tundisi, 2003). Research on net cages indicated that some impacts on the aquatic environment may be registered at various ecological organization levels due to the increase in system productivity (Demir et al., 2001; Yiyong et al., 2001; Guo and Li, 2003; Abery et al., 2005; Santos et al., 2009; Borges et al., 2010; Dias et al., 2011), modifying ecosystem processes such as matter cycling and energy flow.

Several neotropical species have life histories with strategies for tolerating natural environmental variation (e.g., natural disturbance) (Wellborn et al., 1996) as a way of establishing their population. However, concerning anthropogenic activities (e.g., overexploitation, water pollution, destruction and degradation of habitats), there is more environmental stress and it may overwhelm the species' ability to tolerate such disturbances. These activities threaten the system's integrity via biological diversity or even ecosystem properties such as productivity, decay rate, nutrient cycling, resistance and resilience (Loreau et al., 2002; Hooper et al., 2005).

Research has shown that aquatic communities respond differently to natural and anthropogenic disturbances (Angeler and Moreno, 2007; Fraterrigo and Rusak, 2008). Some disturbances exceed the normal range of organisms' tolerance, causing an adverse effect on the populations (Vinebrooke et al., 2004). Once disturbed, a community may resist without changes to its structure, remaining in "equilibrium" (resistance). Sometimes, this situation involves a shift toward a new community structure due to different environmental conditions established by the disturbance, or structural modifications for a given time interval, returning to the previous conditions of the disturbance, i.e., the "equilibrium". Furthermore, the disturbance may change the balance and dynamic around it, when it is sufficiently strong (Ives and Carpenter, 2007). These scenarios might include a multi-specific dynamic, in the face of population oscillations, which serves as a starting point for a more precise characterization of the natural system (DeAngelis and Waterhouse, 1987).

The ability to show recovery behavior regarding one disturbance over time is termed resilience (Pimm, 1984; Gunderson, 2000). Resilience is also the ability of the system to absorb changes without alterations to its original state (Holling, 1973). However, in practice, the first definition may be objectively accessible using simple mathematical representations. Taking this into account, the abundance fluctuations of aquatic communities as an indicator of community resilience to a disturbance can be considered. Productivity increase during fish farming activities changes the dynamics of energy flow, which will affect the structure of planktonic communities in the environment. Gliwicz (2002) pointed out that the increase in productivity increases rates of individual growth and reproduction of zooplankton organisms and thereafter the rapid increase in population abundance. These community responses demonstrate their importance in maintaining ecosystem stability, since these organisms link the primary producers to consumers (Lampert, 1997).

The object of this study was to evaluate zooplankton community resilience after net cage installation for fish farming in a subtropical reservoir. We predicted that aquaculture practice affects natural dynamics of the zooplankton community because the increase in the system's production modifies the ability of responses of these organisms.

\section{Material and Methods}

\subsection{Study area}

Rosana Reservoir $\left(22^{\circ} 36^{\prime} \mathrm{S}\right.$ and $\left.52^{\circ} 52^{\prime} \mathrm{W}\right)$ (Figure 1) is situated in the low stretch of the Paranapanema River, at $20 \mathrm{~km}$ from its mouth in the Paraná River (São Paulo and Paraná States). This reservoir presents $220 \mathrm{~km}^{2}$ of area, $116 \mathrm{~km}$ of extension, an average depth of $12 \mathrm{~m}$ in fluvial and transition regions, and $30 \mathrm{~m}$ in the lacustrine region. The average residence time is 18.6 days. The present study was developed during the winter (dry period) in a lateral arm from this reservoir (Guairacá Stream) whose catchment area is predominantly categorized as a rural environment, where settlement areas and properties are used for agriculture, pasture and reforestation.

\subsection{Sampling design}

Samplings of abiotic and biotic data were carried out in triplicate at six sampling stations located along the principal axis of the lateral arm of the reservoir. Three sampling stations were set up close to each treatment net cage, one sampling station at $400 \mathrm{~m}$ upstream from the net cages (control), and two sampling stations at 100 and $400 \mathrm{~m}$ downstream from the net cages, respectively. Net cages with different densities of Nile tilapia (Oreochromis niloticus L.) $\left(50 \mathrm{~kg} \cdot \mathrm{m}^{-3}, 75 \mathrm{~kg} \cdot \mathrm{m}^{-3}, 100 \mathrm{~kg} \cdot \mathrm{m}^{-3}\right)$ were installed in triplicate from 7 April to 9 August-06. The cages had dimensions of $2 \times 2 \times 1.7 \mathrm{~m}$. Fish were fed a quantity of ration three times a day determined by the total biomass, which is dependent on weight gain over time.

The first sampling (T0) was taken before the net cage was installed, and this sampling was established as a reference to evaluate the resilience (control period). We assumed that the abundance from the different zooplankton groups at $\mathrm{T} 0$ would be equivalent to those recorded for the ecosystem in the previous environmental conditions. After 


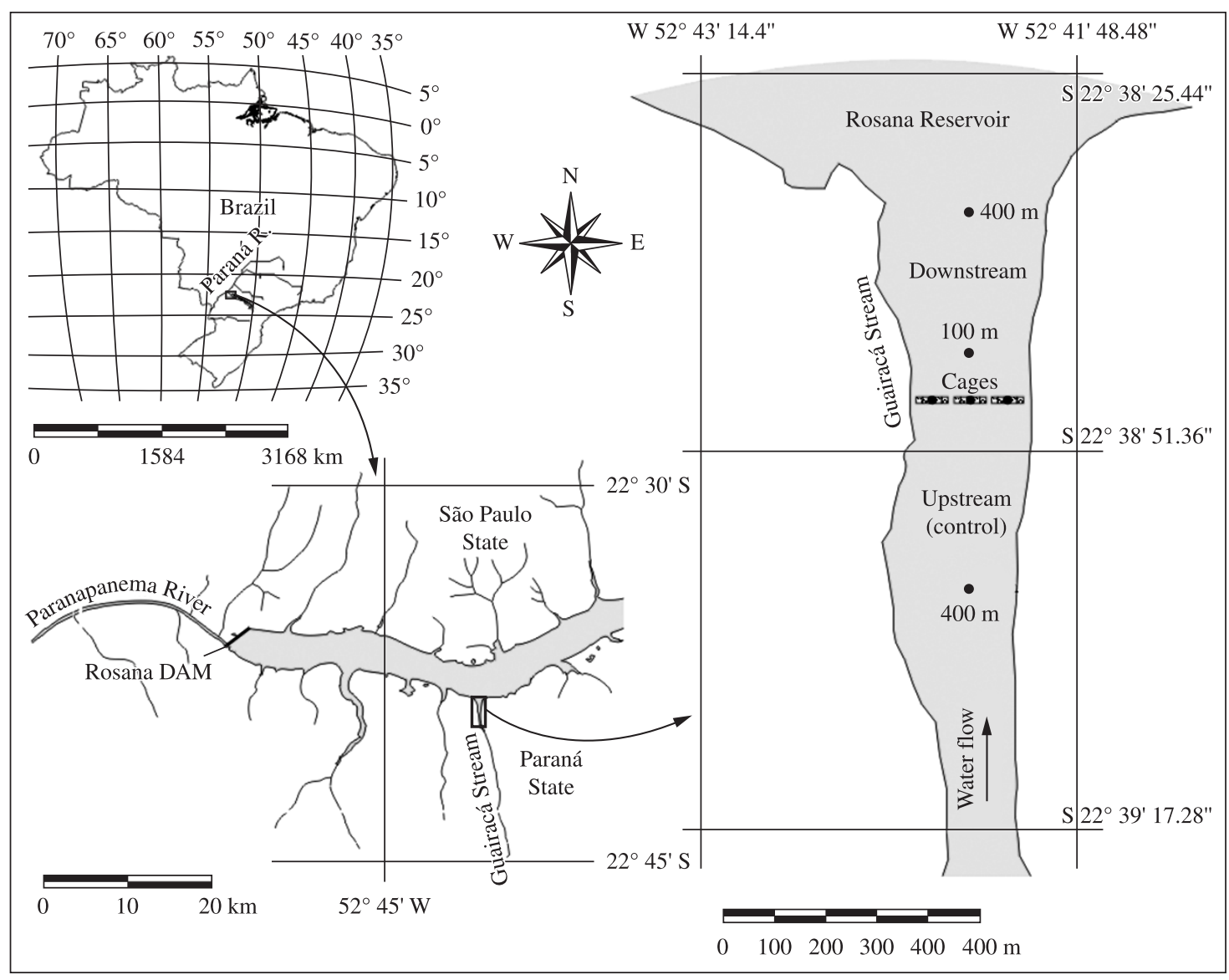

Figure 1. Study area showing the lateral arm from Rosana Reservoir (lacustrine region) where the experiment was performed (Guairacá Stream), near the confluence with the Paranapanema River.

installing the net cage, the environment was monitored for 120 days. The subsequent samplings were performed 15 (T1), 30 (T2), 60 (T3), 90 (T4) and 120 (T5) days after the net cage was installed. This sampling design was similar to before-after control-impact (BACI): measurements were taken before (T0) and after (T1, T2, T3, T4 and T5) the net cage installation; at the impacted sites (close net cages) and control site (upstream $400 \mathrm{~m}$ ). Taking this into account, the system's natural variation may be evaluated using the control site. Downstream measures were used to verify if the disturbance only had an influence on close sites from net cage installation, or whether it also influenced the localities of 100 and $400 \mathrm{~m}$ downstream.

\subsection{Data collection}

The following environmental variables were measured: water temperature $\left({ }^{\circ} \mathrm{C}\right)$, dissolved oxygen $\left(\mathrm{mg} . \mathrm{L}^{-1}\right)$ (YSI Model 55-12FT digital portable oximeter), conductivity $\left(\mu \mathrm{S} . \mathrm{cm}^{-1}\right)$ (Digimed digital portable conductivimeter), $\mathrm{pH}$ (Digimed digital portable $\mathrm{pH}$ meter), and total alkalinity (mEq.L $\mathrm{L}^{-1}$ ) (Carmouze, 1994).

Water samples were collected using a van Dorn bottle $(5 \mathrm{~L})$ to determine the concentrations of total nitrogen $(\mu \mathrm{M})$ (Mackereth et al., 1978), nitrate $(\mu \mathrm{M})$
(Giné et al., 1980), ammonium ( $\mu \mathrm{M})$ (Mackereth et al., 1978), total phosphorus ( $\mu \mathrm{M})$ (Golterman et al., 1978), phosphate $(\mu \mathrm{M})$ (Mackereth et al., 1978), chlorophyll- $a$ $\left(\mu \mathrm{g} . \mathrm{L}^{-1}\right)$ (Golterman et al., 1978), inorganic suspended material $\left(\mu \mathrm{g} . \mathrm{L}^{-1}\right)$ and organic suspended material $\left(\mu \mathrm{g} . \mathrm{L}^{-1}\right)$ (Teixeira et al., 1965).

Zooplankton organisms were sampled at subsurface regions extending from the pelagic region, during the morning, using a motorized pump to filter $200 \mathrm{~L}$ of water through a plankton net $(68 \mu \mathrm{m})$. The organisms were preserved in formaldehyde solution (4\%) buffered with calcium carbonate.

Abundance of the different groups was estimated by at least three subsamplings using a Hensen-Stempell pipette $(2.5 \mathrm{~mL})$ and counting at least 50 individuals from each group (Bottrell et al., 1976), in Sedgewick-Rafter chambers, under an optical microscope. Samples with low numbers of individuals were integrally quantified. The total abundance was expressed as individuals per cubic meter (ind. $\mathrm{m}^{-3}$ ).

\subsection{Data analysis}

The Principal Component Analysis (PCA) was used to compare environmental characteristics and temporal 
variation. Data were standardized by a correlation matrix. This analysis was performed using PC-ORD software version 4.01 (McCune and Mefford, 1999).

For deterministic systems, resilience has been quantitatively associated with the return rate of the system to equilibrium after an environmental disturbance (Pimm, 1984). In natural systems, the deterministic equilibrium is never reached. However, resilience may be measured by the proximity of variability around the mean of the established metric (Ives, 1995). Considering that the present study is an experimental study, where stress was monitored, the resilience was measured using a mathematical function to characterize the change in zooplankton abundance during a time interval, according to Pimm (1991). Therefore, we used the sum of species abundance from each group as an aggregated property.

A first-order function was adjusted to interpret the resilience in the different zooplankton groups, described by $y=a x+b$, where $\mathrm{y}$ is the abundance (Napierian logarithm), $\mathrm{x}$ is the time; $a$ is the slope coefficient, which is characterized by the return rate (i.e., resilience), and $b$ is the intercept. The slope is the parameter that indicates line inclination: while the more negative the value is, the more resilient the group is. Coefficient " $b$ " does not show biological significance and was used analytically to verify the linearity of the regression. The significance of the function was estimated by a simple regression analysis, observing the assumptions of normality (Shapiro-Wilk Test of standard residuals) and homoscedasticity (residual visualization). We assumed that the measurements are independent and not serially correlated.
Finally, an analysis of variance was used in order to test differences of the resilience rate (slope) among the zooplankton groups.

\section{Results}

\subsection{Environmental variables}

The PCA analysis described $82.10 \%$ of total data variability along the first five axes and $52.91 \%$ in the first two axes (Table 1). Temperature, chlorophyll- $a$, inorganic and organic material, $\mathrm{pH}$, conductivity and total phosphorus were negatively correlated with axis 1 , while the total nitrogen, nitrate and ammonium were positively correlated with this axis. Temperature, alkalinity, nitrate, total phosphorus and phosphate were negatively more important to axis 2, while chlorophyll-a, organic material, dissolved oxygen, total nitrogen were positively associated with this axis 2 .

Score distribution showed a clear temporal variation (Figure 2). In the bi-dimensional ordination (Figure 2), the sampling previous to the installation of the net cages (T0) registered higher values of $\mathrm{NO}_{3}(1.32-5.71 \mu \mathrm{M})$ and lower values of $\mathrm{pH}$ (7.26-7.41), alkalinity (416.80-429.90 mEq.L-1 and fractions of suspended solids (inorganic: 0.36-0.68 $\mu \mathrm{g} . \mathrm{L}^{-1}$; organic: $0.44-0.64 \mu$ g.L $\mathrm{L}^{-1}$ ) (Table 2). On the other hand, samplings $\mathrm{T} 1$ and $\mathrm{T} 2$ presented environmental conditions that contrasted with those recorded at $\mathrm{T0}: \mathrm{NO}_{3}(4.01-4.81 \mu \mathrm{M})$, pH (7.08-8.76), alkalinity (331.70-464.70 mEq.. $\left.{ }^{-1}\right)$ and fractions of suspended solids (inorganic: 0.14-0.96 $\mu \mathrm{g} . \mathrm{L}^{-1}$; organic: $0.49-52 \mu \mathrm{g} . \mathrm{L}^{-1}$ ). The T3 sampling presented conditions similar to T0 . However, the subsequent

Table 1. Results from Principal Component Analysis during the experiment in Guairacá Stream, lateral arm from Rosana Reservoir (Paranapanema River) from April to August 2006.

\begin{tabular}{|c|c|c|c|c|c|}
\hline & Axis 1 & Axis 2 & Axis 3 & Axis 4 & Axis 5 \\
\hline Eigenvalue & 3.82 & 3.06 & 1.52 & 1.27 & 1.00 \\
\hline Percentage variance & 29.38 & 23.53 & 11.68 & 9.76 & 7.73 \\
\hline Cumulative percentage variance & 29.38 & 52.91 & 64.58 & 74.35 & 82.07 \\
\hline \multicolumn{6}{|l|}{$r$-pearson } \\
\hline Temperature & $-0.69 *$ & $-0.65^{*}$ & -0.18 & 0.00 & 0.14 \\
\hline Chlorophyll- $a$ & $-0.26 *$ & $0.29 *$ & $0.32 *$ & $-0.75^{*}$ & -0.07 \\
\hline Inorganic material & $-0.72 *$ & 0.16 & $-0.33 *$ & 0.03 & -0.18 \\
\hline Organic material & $-0.68 *$ & $0.51^{*}$ & 0.18 & 0.13 & -0.02 \\
\hline $\mathrm{pH}$ & $-0.94 *$ & -0.07 & 0.07 & 0.12 & -0.12 \\
\hline Alkalinity & -0.11 & $-0.44^{*}$ & $0.55^{*}$ & -0.24 & -0.18 \\
\hline Conductivity & $-0.77^{*}$ & 0.02 & 0.08 & $0.50 *$ & -0.01 \\
\hline Dissolved oxygen & -0.03 & $0.82 *$ & 0.22 & 0.21 & $-0.36 *$ \\
\hline Total nitrogen & $0.47 *$ & $0.73^{*}$ & 0.22 & 0.23 & -0.14 \\
\hline Nitrate & $0.55^{*}$ & $-0.57^{*}$ & -0.15 & $0.36^{*}$ & -0.16 \\
\hline Ammonium & $0.34 *$ & -0.23 & $0.66^{*}$ & $0.35 *$ & $0.26^{*}$ \\
\hline Total phosphorus & $-0.30 *$ & $-0.54^{*}$ & $0.60 *$ & 0.06 & -0.12 \\
\hline Phosphate & $0.24 *$ & $-0.44 *$ & -0.10 & -0.02 & $-0.80 *$ \\
\hline
\end{tabular}

*Significant correlation of the variable in the respective axis; $p<0.01$. 
Table 2. Temporal variation in environmental variables registered during the study period in the Guairacá Stream, at the lateral arm from Rosana Reservoir (Paranapanema River).

\begin{tabular}{lcccccc}
\hline $\begin{array}{c}\text { Environmental } \\
\text { variables }\end{array}$ & T0 & T1 & T2 & T3 & T4 & T5 \\
\hline Temperature & $26.00-26.20$ & $25.50-26.70$ & $23.20-28.50$ & $23.40-24.40$ & $21.70-24.30$ & $20.30-23.30$ \\
Chlorophyll- $a$ & $1.20-2.60$ & $1.02-6.14$ & $0.68-6.14$ & $1.95-4.29$ & $0.55-3.12$ & $1.64-5.46$ \\
Inorganic material & $0.36-0.68$ & $0.32-1.28$ & $0.14-0.96$ & $0.07-0.52$ & $0.07-1.00$ & $0.20-0.90$ \\
Organic material & $0.44-0.64$ & $0.40-1.12$ & $0.49-1.52$ & $0.28-0.84$ & $0.42-1.20$ & $0.72-1.20$ \\
pH & $7.26-7.41$ & $7.65-7.81$ & $7.08-8.76$ & $6.95-7.25$ & $6.95-7.28$ & $7.06-7.66$ \\
Alkalinity & $416.80-429.90$ & $398.20-452.60$ & $331.70-464.70$ & $383.20-51.60$ & $350.40-39.70$ & $383.10-550.30$ \\
Conductivity & $57.80-59.10$ & $59.30-67.00$ & $58.60-71.00$ & $58.20-59.10$ & $58.50-61.70$ & $57.90-63.70$ \\
Dissolved oxygen & $6.27-7.72$ & $6.70-7.17$ & $6.86-7.92$ & $6.73-7.33$ & $7.17-8.81$ & $8.00-8.80$ \\
Total nitrogen & $33.16-36.47$ & $31.77-42.94$ & $29.65-42.84$ & $35.45-44.22$ & $39.59-58.73$ & $44.32-54.25$ \\
Nitrate & $1.32-5.71$ & $3.45-5.02$ & $4.01-4.81$ & $4.70-5.24$ & $4.46-5.30$ & $4.04-4.85$ \\
Ammonium & $0.19-0.42$ & $0.02-0.72$ & $0.19-0.69$ & $0.25-1.28$ & $0.12-0.95$ & $0.05-0.65$ \\
Total phosphorus & $0.43-0.54$ & $0.33-0.82$ & $0.45-0.68$ & $0.42-0.58$ & $0.30-0.63$ & $0.30-0.66$ \\
Phosphate & $0.09-0.10$ & $0.03-0.07$ & $0.04-0.14$ & $0.04-0.12$ & $0.03-0.11$ & $0.04-0.08$ \\
\hline
\end{tabular}

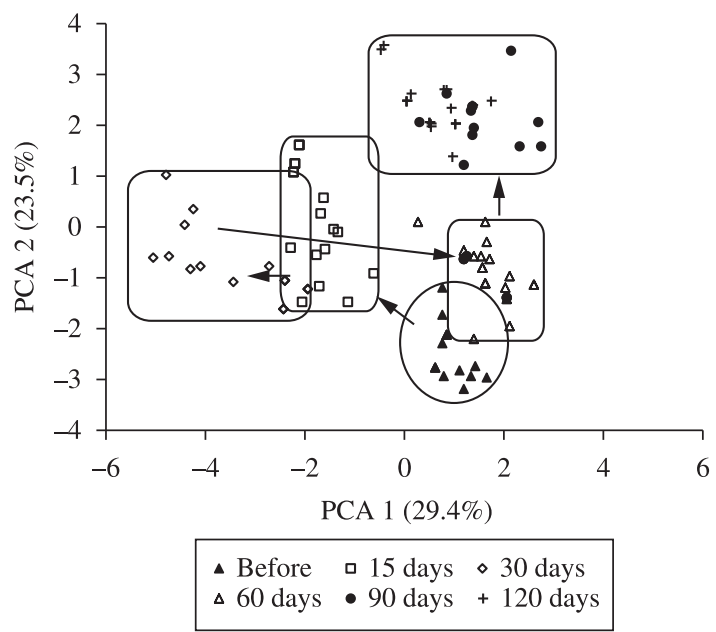

Figure 2. Temporal trend of environmental variables summarized by the PCA (Principal Component Analysis) twodimensional diagram.

samplings (T4 and T5) presented a second temporal trend, characterized by a trophic variation in the environment, compatible with nutrient concentrations, mainly due to an increase in the total nitrogen concentration (PCA 2) (Table 1).

Another trend that characterized the productivity gradient was related to PCA 4, which was mainly influenced by the chlorophyll- $a$ concentration that was lower in T0 . It presented peaks at $\mathrm{T} 1$ and $\mathrm{T} 2$, and presented higher values at $\mathrm{T} 3$ and $\mathrm{T} 4$ than those observed before the experiment (T0), as well as lower values than those observed at T1 and T2.

\subsection{Zooplankton community resilience}

The zooplankton community was represented by 106 species, consisting of rotifers (72 species, 67.9\%), cladocerans (23 species, $21.7 \%$ ) and copepods (11 species,
$10.4 \%$ ) (Table 3). The most abundant species were Synchaeta pectinata, S. oblonga, Conochilus coenobasis, Polyarthra dolichoptera and C. unicornis (Rotifera), Ceriodaphnia cornuta, Moina minuta, Bosmina hagmanni and $C$. silvestrii (Cladocera) and Notodiaptomus amazonicus (Copepoda).

The abundance of zooplankton varied with the same magnitude at all sites (control, cage culture and downstream), suggesting cage cultures were not the main reason of temporal variation of the zooplankton abundance. However, these aquaculture practices affected the resilience of this community.

Microcrustacean abundance at the end of the experiment showed similar values registered before the beginning of the experiment. Cladocerans and calanoid copepods were numerically important at T2 (day 30) (Figure 3a,b) and cyclopoid copepods presented peaks of abundance at T1 (day 15) (Figure 3c). A decrease in the abundance of cladocerans, calanoid and cyclopoid copepods followed a linear function, with significant intercept and slope coefficient $(\mathrm{p}<0.001)$. The microcrustaceans resilience (function's slope) was lower at cage culture sites (Figure 3ac). In general, it could be observed that rotifers were not resilient due to their abundance which showed an increase from T0 to T5, with peaks at T1 and T5 (Figure 3d).

Control, downstream $100 \mathrm{~m}$ and downstream $400 \mathrm{~m}$ sites had higher slopes, indicating that these sites had similar resilience rates. The return rate (function's slope) was different among the groups (Figure 4), especially for Cyclopoida copepods, which showed lower slopes ranging from -0.446 to -0.665 .

\section{Discussion}

Temporal changes in environmental conditions were observed in the short and long terms. Short-term changes occurred during the first 30 days after installing the net cage, when higher values of $\mathrm{pH}$, suspended solids and 
Table 3. List of zooplankton species registered during the study period in the Guairacá Stream at the lateral arm from Rosana Reservoir (Paranapanema River).

\begin{tabular}{|c|c|}
\hline Rotifera & TESTUDINELLIDAE \\
\hline BRACHIONIDAE & Pompholyx triloba Pejler, 1957 \\
\hline Brachionus calyciflorus Pallas, 1766 & Testudinella patina (Hermann, 1783) \\
\hline B. dolabratus Harring, 1914 & TRICHOCERCIDAE \\
\hline B. falcatus Zacharias, 1898 & Trichocerca bicristata (Gosse, 1887) \\
\hline B. mirus Daday, 1905 & T. bidens (Lucks, 1912) \\
\hline Keratella americana Carlin, 1943 & T. capucina (Wierzejski \& Zacharias, 1893) \\
\hline K. cochlearis (Gosse, 1851$)$ & T. cylindrica (Imhof, 1891) \\
\hline K. lenzi Hauer, 1953 & T. gracilis (Tessin, 1890) \\
\hline K. tropica (Apstein, 1907) & T. iernis (Gosse, 1887) \\
\hline Plationus patulus macracanthus (Daday, 1905) & T. insignis (Herrick, 1885) \\
\hline P. patulus patulus (Müller, 1786) & T. pusilla (Jennings, 1903) \\
\hline Platyias quadricornis quadricornis (Ehrenberg, 1832) & T. similis (Wierzejski, 1893) \\
\hline P. quadricornis brevispinus (Daday, 1905) & TRICHOTRIIDAE \\
\hline CONOCHILIDAE & Macrochaetus collinsii (Gosse, 1867) \\
\hline Conochilus coenobasis (Skorikov, 1914) & M. sericus (Thorpe, 1893) \\
\hline C. dossuarius Hudson, 1885 & Trichotria tetractis tetractis (Ehrenberg, 1830) \\
\hline C. unicornis Rousselet, 1892 & FILINIDAE \\
\hline DICRANOPHORIDAE & Filinia longiseta (Ehrenberg, 1834) \\
\hline Dicranophorus epicharis Harring \& Myers, 1928 & F. opoliensis (Zacharias, 1898) \\
\hline D. prionacis Harring \& Myers, 1928 & Bdelloidea \\
\hline Dicranophorus sp. & Cladocera \\
\hline EUCHLANIDAE & BOSMINIDAE \\
\hline Dipleuchlanis propatula (Gosse, 1886) & Bosmina hagmanni Stingelin, 1904 \\
\hline Euchlanis dilatata dilatata Ehrenberg, 1832 & Bosminopsis deitersi Richard, 1895 \\
\hline E. dilatata luckisiana Hauer, 1930 & CHYDORIDAE \\
\hline E. incisa Carlin, 1939 & Alona guttata Sars, 1862 \\
\hline FLOSCULARIIDAE & A. guttata cf. tuberculata Kurz, 1875 \\
\hline Floscularia ringens (Linnaeus, 1758) & Alona ossiani Sinev, 1998 \\
\hline Floscularia sp. & A. verrucosa Sars, 1901 \\
\hline Octoctrocha speciosa Thorpe, 1893 & Alona sp. \\
\hline Ptygura sp. & Alonella dadayi Birge, 1879 \\
\hline Sinantherina spinosa (Thorpe, 1893) & Camptocercus australis Sars, 1896 \\
\hline GASTROPODIDAE & Chydorus eurynotus Sars, 1901 \\
\hline Ascomorpha ecaudis Perty, 1850 & Chydorus pubescens Sars, 1901 \\
\hline A. saltans Bartsch, 1870 & Disparalona hamata (Birge, 1879) \\
\hline HEXARTHRIDAE & Notoalona sp. \\
\hline Hexarthra intermedia (Wiszniewski, 1929) & DAPHNIIDAE \\
\hline H. mira (Hudson, 1871) & Ceriodaphnia cornuta Sars 1886 \\
\hline LECANIDAE & C. silvestrii Daday, 1902 \\
\hline Lecane bulla (Gosse, 1851) & Daphnia gessneri Herbst, 1967 \\
\hline L. cornuta (Müller, 1786) & Simocephalus latirostris Stingelin, 1906 \\
\hline L. curvicornis (Murray, 1913) & ILYOCRYPTIDAE \\
\hline L. elsa Hauer, 1931 & Ilyocryptus spinifer Herrick, 1882 \\
\hline L. hamata (Stokes, 1896) & MACROTHRICIDAE \\
\hline L. hornemanni (Ehrenberg, 1834) & Macrothrix elegans Sars, 1901 \\
\hline L. latissima Yamamoto, 1955 & M. squamosa Sars, 1901 \\
\hline
\end{tabular}


Table 3. Continued...

\begin{tabular}{|c|c|}
\hline Rotifera & TESTUDINELLIDAE \\
\hline L. leontina (Turner, 1892) & MOINIDAE \\
\hline L. luna (Müller, 1776) & Moina minuta (Hansen, 1899) \\
\hline L. lunaris (Ehrenberg, 1832) & SIDIDAE \\
\hline L. proiecta Hauer, 1956 & Diaphanosoma birgei Korineck, 1981 \\
\hline L. pusilla Harring, 1914 & D. spinulosum Herbst, 1967 \\
\hline L. signifera (Jennings, 1896) & Copepoda \\
\hline MYTILINIDAE & CYCLOPIDAE \\
\hline Mytilina ventralis (Ehrenberg, 1830) & Eucyclops sp. \\
\hline NOTOMMATIDAE & Mesocyclops aspericornis (Daday, 1906) \\
\hline Enteroplea lacustris Ehrenberg, 1830 & M. ellipticus Kiefer, 1936 \\
\hline Notommata cerberus (Gosse, 1886) & M. longisetus curvatus Dussart, 1987 \\
\hline N. pachyura (Gosse, 1886$)$ & M. meridianus (Kiefer, 1926) \\
\hline Notommata sp. & M. ogunnus Onabamiro, 1957 \\
\hline SYNCHAETIDAE & Thermocyclops decipiens Kiefer, 1929 \\
\hline Ploesoma truncatum (Levander, 1894) & T. minutus (Lowndes, 1934) \\
\hline Polyarthra dolichoptera Idelson, 1925 & DIAPTOMIDAE \\
\hline P. vulgaris Carlin, 1943 & Argyrodiaptomus azevedoi (Wright, 1935) \\
\hline Synchaeta oblonga Ehrenberg, 1832 & Notodiaptomus amazonicus (Wright, 1935) \\
\hline S. pectinata Ehrenberg, 1832 & N. henseni (Dahl, 1894) \\
\hline S. stylata Wierzejski, 1893 & \\
\hline
\end{tabular}

chlorophyll- $a$ were recorded, reflecting a fast increase in system productivity. Over the long term, we observed an increase in system productivity by an increase in the concentrations of chlorophyll- $a$, total nitrogen and suspended organic solids. This shift of productivity reveals the change in ecosystem properties, which may influence the stability of their communities (Tilman et al., 1996).

The disturbing effect (net cages) on the abundance of zooplankton groups was not clear because of the high environmental variation observed in the control site. Previous studies during 2001 (Lansac-Tôha et al., 2005), 2004 and 2005 (unpublished data) recorded similar abundances that were observed in the beginning of this study (T0) in the same reservoir (original conditions of the environment). In general, the nutrient input in the aquatic environments may act as a disturbance that produces a pulse effect and renders the environment more productive, consequently increasing the abundance and biomass of plankton organisms (Angeler et al., 2000; Carpenter et al., 2001; Pinto-Coelho et al., 2005). In the net cage culture, management involves a continuous addition of energy into the aquatic environment due to daily feeding. Part of the unconsumed rations, excreted and metabolic residuals from fish were released to the environment and acted as allochthonous resources of energy, changing the primary and secondary production.

Our main results showed that the microcrustaceans' resilience was affected in cage culture sites. At these sites, the rates of decrease (slope) of the abundance of microcrustaceans were lower because the aquaculture practice left a productive environment for longer, showing the decline of the abundance. At the control site, the abundance decreased more rapidly because the productivity was sustained only by natural variation. Sites located downstream had similar slopes in respect to the control locality, probably due to dissipation of the energy received from the net cages, and only natural variation remained.

The return time of microcrustaceans ranged from 30 to 90 days after the abundance peak, showing that, even with the disturbance in the reservoir, cladocerans, calanoid and cyclopoid copepods were able to return to initial conditions, but with different temporal discrepancies.

Calanoid copepods, which presented higher resilience, are considered by Matsumura-Tundisi and Tundisi (2003) as highly sensitive to environmental conditions, due to both nutrient input and the physical stability of the environment. Probably, the decrease in food resources due to Cyanobacteria bloom, mainly Radiocystis fernandoi (Borges et al., 2010), contributed to a decrease in the abundance of these copepods because they are mainly adults and, therefore, more selective when searching for food (Allan, 1976; Pennak, 1989). The fast decrease in the abundance of these organisms may also be related to the $\mathrm{k}$-strategist behavior, with longer growth period, and more stable environmental conditions (Nogueira, 2001). Cladocerans presented an intermediate resilience as compared to calanoid and cyclopoid copepods. Although opportunistic among microcrustaceans, they are unable to achieve the 


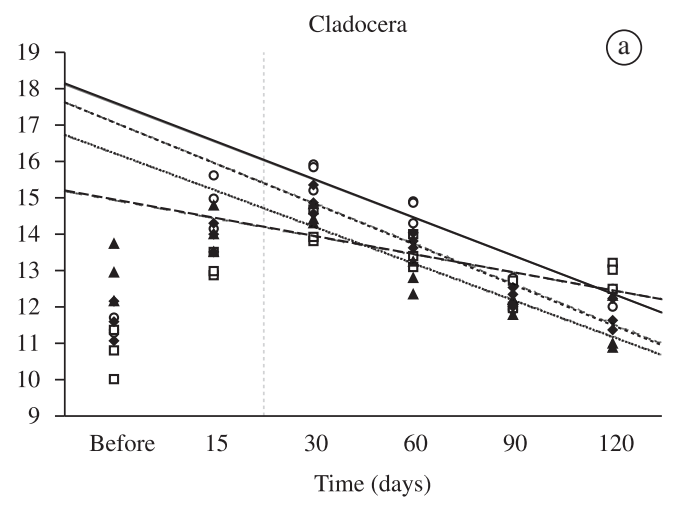

- Control $(\mathrm{a}=1.044 ; \mathrm{p}<0.001)$

a Cage culture $(\mathrm{a}=0.628 ; \mathrm{p}<0.001)$

- Downstream $100 \mathrm{~m}(\mathrm{a}=1.106 ; \mathrm{p}<0.001)$

\ Downstream $400 \mathrm{~m}(\mathrm{a}=1.169 ; \mathrm{p}<0.001)$

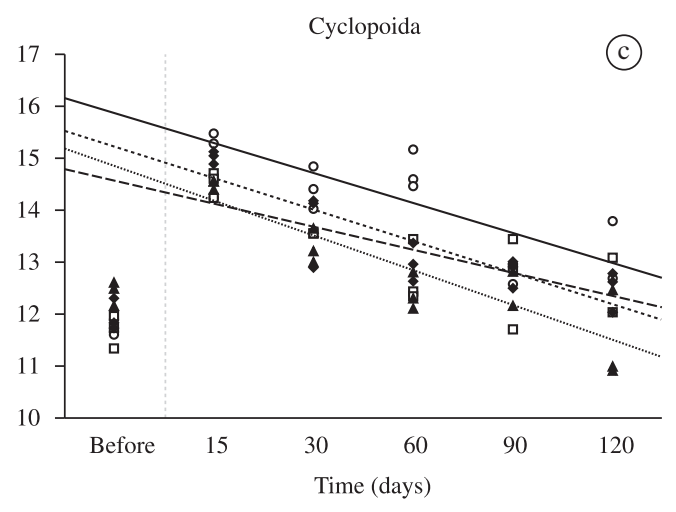

- Control $(\mathrm{a}=0.581 ; \mathrm{p}<0.001)$

a Cage culture $(\mathrm{a}=0.446 ; \mathrm{p}<0.001)$

- Downstream $100 \mathrm{~m}(\mathrm{a}=0.661 ; \mathrm{p}<0.001)$

$\Delta$ Downstream $400 \mathrm{~m}(\mathrm{a}=0.675 ; \mathrm{p}<0.001)$

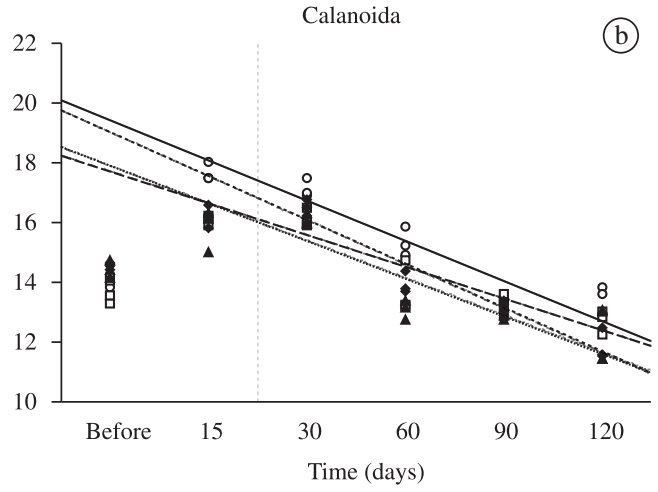

- Control $(\mathrm{a}=1.2343 ; \mathrm{p}<0.001)$

口 Cage culture $(\mathrm{a}=1.063 ; \mathrm{p}<0.001)$

- Downstream $100 \mathrm{~m}(\mathrm{a}=1.470 ; \mathrm{p}<0.001)$

\ Downstream $400 \mathrm{~m}(\mathrm{a}=1.248 ; \mathrm{p}<0.001)$

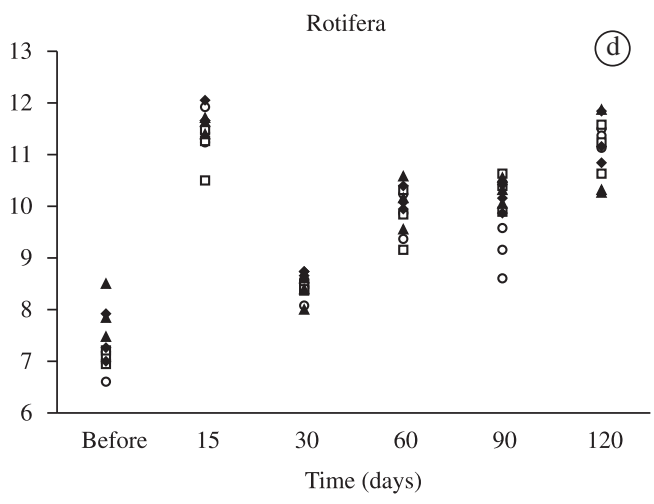

- Control a Cage culture

- Downstream $100 \mathrm{~m}$ ॥ Downstream $400 \mathrm{~m}$

Figure 3. Decrease in abundance of microcrustaceans recorded during different sampling periods in Guairacá Stream, at the lateral arm from Rosana Reservoir (Paranapanema River).

biotic potential of rotifers (Allan, 1976) and are subjected to higher predation pressure by both fish (Rejas et al., 2005) and invertebrates. The lower resilience of cyclopoid copepods, with an observed return of 90 days after the disturbance, was probably related to a resistance of these microcrustaceans to environmental variations and a better adaptation to meso-eutrophic conditions (Nogueira, 2001; Silva and Matsumura-Tundisi, 2002), e.g., the versatility in feeding habits (Reid, 1985) reflected a better adaptive adjustment to new conditions in the reservoir. Particularly, the life cycle of copepods has morpho-physiological modifications during their ontogenetic development that favor the establishment of populations even under highly variable conditions. Therefore, these stages of the life cycle explore different resources and favor the occupation of different trophic levels in food chains.

According to Pimm (1991), resilient communities are those with high reproductive rates, due to their short life cycle, which allows rapid population growth after a disturbance. However, this study did not corroborate this statement, since rotifers did not present resilience, because the disturbance (as an increase in aquatic production) increased their abundances, contradicting most results and discussions in the literature (Mäemets, 1983; Pejler, 1983). Some arguments are based on the resistance that rotifers show when facing various environmental impacts (Matsumura-Tundisi et al., 1990; Matsumura-Tundisi and Tundisi, 2005), mainly due to demographic features (high birth rate, fast life cycle and excellent potential for colonization in the absence of environmental constraints) that characterize them as opportunist (Allan, 1976); or due to recolonization strategies, such as resting eggs (Palazzo et al., 2008). Nevertheless, we believe that behavioral traits of opportunist species may also have contributed to these results, especially because the biotic potential of these species is magnified under more productive conditions (Matsumura-Tundisi et al., 1990; Aoyagui et al., 2003; Lansac-Tôha et al., 2005). 


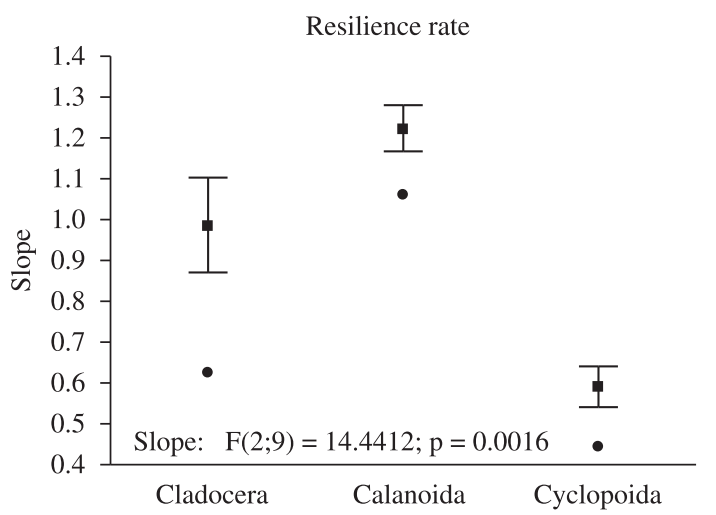

Figure 4. Resilience rate of the zooplankton groups (symbol $=$ mean; bar $=$ standard error; circles $=$ resilience rate in the cage culture).

The consequences of the absence of resilience showed by rotifers may be "dangerous" for the environment. These organisms occupy the trophic niche of small filter-feeding organisms (Margalef, 1983), and a change in this process of energy transference may affect the structure and dynamics of other assemblages which are directly or indirectly related to these primary consumers, which have a wide range of preference for food resources (from bacteria to filamentous algae). This suggests that the rotifers tended to be of a different stability domain (alternative equilibria state, Scheffer et al., 1993; Scheffer and van Nes, 2007), probably due to the altered environmental conditions. However, we need to emphasize that a functional compensation may occur when changes in species composition do not modify ecosystem function (Loreau et al., 2002). These facts are extremely important for the maintenance of the trophic web of the system and consequently the stability.

Probably, peculiarities in patterns of life history related to birth and death rates, reproductive aspects and feeding habits among zooplankton groups are the main factors necessary to characterize the resilience of the zooplankton community in the present study. The sensitiveness of these attributes to environmental fluctuations characterizes the variability of species abundances and the return time to equilibrium in deterministic systems or around mean abundances in stochastic systems (Ives, 1995). Furthermore, the strategy when using food resources was one of the factors that influenced resilience among zooplankton organisms. According to Lampert and Sommer (2007), species with higher reproductive rates, such as rotifers, may promptly use the food resources for reproduction in order to compensate loss of time when these resources are scarce. On the other hand, organisms such as microcrustaceans invest in the formation of energy reserves that allow them to maximize resources use during short periods with abundant food.

The community resilience, as a property of ecological stability, aids in ecosystem management (Gunderson, 2000), facilitating resistance to environmental changes. This community property indicates the disturbance levels and consequently may suggest management activities, since the disturbances change the rate of population growth, biotic interactions, biomass production, and various other processes affecting ecosystem functioning (Ives and Carpenter, 2007).

\section{Final considerations}

The approach of zooplankton community resilience showed that the cage culture installation affected the natural response of zooplankton community. Thus our prediction was confirmed because this aquaculture practice modified the zooplankton community resilience. However its effect was perceived locally (cage culture). Concerning a costbenefit relationship between damage to biodiversity and the production of natural resources, we suggest further study on energy transfer between producers and secondary consumers. Therefore, management strategies would cause fewer risks to cladocerans and copepods and maximize the energy flow which will help maintain system stability.

Acknowledgements - The present study was supported by Capes/Proex, an Brazilian Government Agency for the training of human resources. The authors would like to thank Dra. Liliana Rodrigues for the suggestions; Nupélia and the Postgraduation Program for logistic support; Capes and CNPq for scholarships and productivity scholarship for CCB.

\section{References}

ABERY, N., F. SUKADI, A. BUDHIMAN, E. KARTAMIHARDJA, S. KOESHENDRAJANA and SILVA S., 2005. Fisheries and cage culture of three reservoirs in west Java, Indonesia, a case study of ambitious development and resulting interactions. Fisheries Management and Ecology, vol.12, p.315-330.

ALLAN, J., 1976. Life history patterns in zooplankton. The American Naturalist, vol.110, p.165-180.

ALVES, R.C.P. and BACCARIN, A.E., 2005. Efeito da produção de peixes em tanques-rede sobre sedimentação de material em suspensão e de nutrientes no córrego da Arribata (UHE Nova Avanhandava, Baixo rio Tiete, SP). In NOGUEIRA, M.G., HENRY, R. and JORCIN, A. (Eds). Ecologia de Reservatórios: Impactos potenciais, ações de manejo e sistemas em cascata. São Carlos: Rima Editora. p. 349-377.

ANGELER, D., ALVAREZ-COBELAS, M., ROJO, C. and SANCHEZ-CARRILLO, S., 2000. The significance of water inputs to plankton biomass and trophic relationships in a semiarid freshwater wetland (central Spain). Journal of Plankton Research, vol.22, p.2075-2093.

ANGELER, D. and MORENO J., 2007. Zooplankton community resilience after press-type anthropogenic stress in temporary ponds. Ecological Applications, vol.17, p.1105-1115.

AOYAGUI, A.S.M, BONECKER, C.C. and LANSAC-TÔHA F.A., 2003. Estrutura e dinâmica dos rotíferos no reservatório de Corumbá, Estado de Goiás, Brasil. Acta Scientiarum, vol.25, p.31-39.

BORGES, P.A.F., TRAIN, S., DIAS, J.D. and BONECKER, C.C., 2010. Effects of fish farming on plankton structure in a Brazilian tropical reservoir. Hydrobiologia, vol.649, p.279-291.

BOTTRELL, H., DUNCAN, A., GLIWICZ, Z., GRYGIEREK, E., HERZIG, A., HILLBRICHT-ILKOWSKA, A., KURASAWA, 
H., LARSSON, P. and WEGLENSKA, T., 1976. A review of some problems in zooplankton production studies. Norwegian Journal of Zoology, vol.24, p.419-456.

CARMOUZE, J., 1994. O Metabolismo dos Ecossistemas Aquáticos: fundamentos teóricos, métodos de estudo e análises químicas. São Paulo: Edgard Blücher/FAPESP.

CARPENTER, S., COLE J., HODGSON, J., KITCHELL, J., PACE, M., BADE, D., COTTINGHAM, K., ESSINGTON, T., HOUSER, J. and SCHINDLER, D., 2001. Trophic cascades, nutrients, and lake productivity: whole-lake experiments. Ecological Monographs, vol.71, p. 163-186.

DeANGELIS, D. and WATERHOUSE, J., 1987. Equilibrium and nonequilibrium concepts in ecological models. Ecological Monographs, vol.57, p.1-21.

DEMIR, N., KIRKAGAC, M., PULATSU, S. and BEKCAN, S., 2001. Influence of trout cage culture on water quality, plankton and benthos in an Anatolian dam lake. Israeli Journal of Aquaculture/ Bamidgeh, vol.53, p.115-127.

DIAS, J.D., TAKAHASHI, E.M., SANTANA, N.F. and BONECKER, C.C., 2011. Impact of fish cage-culture on the community structure of zooplankton in a tropical reservoir. Iheringia-Série Zoologia, vol. 101, p. 75-84.

FRATERRIGO, J. and RUSAK, J., 2008. Disturbance-driven changes in the variability of ecological patterns and processes. Ecology Letters, vol.11, p.756-770.

GINÉ, M., BERGAMIN-FILHO, H., ZAGATTO, E. and REIS, B., 1980. Simultaneous determination of nitrate and nitrite by flow injection analysis. Analytica Chimica Acta, vol.114, p.191-197.

GLIWICZ, Z., 2002. On the different nature of top-down and bottom-up effects in pelagic food webs. Freshwater Biology, vol.47, p.2296-2312.

GOLTERMAN, H.L., CLYMO, R.S. and OHMSTAD, M.A.M., 1978. Methods for Physical and Chemical Analysis of Freshwaters, 2nd edn. (IBP Handbook No. 8). Oxford: Blackwell Scientific Publications.

GUNDERSON, L., 2000. Ecological resilience-in theory and application. Annual Review of Ecology and Systematics, vol.31, p.425-439

GUO, L. and LI, Z., 2003. Effects of nitrogen and phosphorus from fish cage-culture on the communities of a shallow lake in middle Yangtze River basin of China. Aquaculture, vol.226, p.201-212.

HOLLING, C., 1973. Resilience and stability of ecological systems. Annual Review of Ecology and Systematics, vol.4, p.1-23.

HOOPER, D.U., CHAPIN III, F.S., EWEL, J.J., HECTOR, A., INCHAUSTI, P., LAVOREL, S., LAWTON, J.H., LODGE, D.M., LOREAU, M., NAEEM, S., SCHMID, B., SETÄLÄ, H., SYMSTAD, A.J., VANDERMEER, J. and WARDLE, D.A., 2005. Effects of biodiversity on ecosystem functioning: a consensus of current knowledge. Ecological Monographs, vol.75, p.3-35.

IVES, A., 1995. Measuring resilience in stochastic systems. Ecological Monographs, vol.65, p.217-233.

IVES, A. and CARPENTER, S., 2007. Stability and diversity of ecosystems. Science, vol.317, p.58-62.

LAMPERT, W., 1997. Zooplankton research: the contribution of limnology to general ecological paradigms. Aquatic Ecology, vol.31, p.19-27.
LAMPERT, W. and SOMMER, U., 2007. Limnoecology: the ecology of lakes and streams. New York: Oxford University Press.

LANSAC-TÔHA, F.A., BONECKER, C.C. and VELHO, L.F.M., 2005. Estrutura da comunidade zooplânctonica em reservatórios. In RODRIGUES, L., THOMAZ, S.M., AGOSTINHO, A.A. and GOMES, L.C. (Eds). Biocenoses em reservatórios: padrões espaciais e temporais. São Carlos: Rima. p.115-196.

LOREAU, M., DOWNING, A., EMMERSON, M., GONZALEZ, A., HUGHES, J., INCHAUSTI, P., JOSHI, J., NORBERG, J. and SALA, O., 2002. A new look at the relationship between diversity and stability. In LOREAU, M., NAEEM, S. and INCHAUSTI, P. (Eds). Biodiversity and ecosystem functioning. Synthesis and perspectives. New York: Oxford University Press. p.79-91.

MACKERETH, F.J.H., HERON, J. and TALLING, J.F., 1978. Water Analysis: Some Revised Methods for Limnologists. Freshwater Biological Association Scientific Publication No. 36. Titus Wilson and Son Ltd, Kendall.

MÄEMETS, A. 1983. Rotifers as indicators of lake types in Estonia. Hydrobiologia, vol.104, p.357-361.

MARGALEF, R., 1983. Limnologia. Barcelona, Omega.

MATSUMURA-TUNDISI, T. and TUNDISI, J.G., 2003. Calanoida (Copepoda) species composition changes in the reservoirs of São Paulo State (Brazil) in the last twenty years. Hydrobiologia, vol.504, p.215-222.

MATSUMURA-TUNDISI, T. and TUNDISI, J. G. 2005. Plankton richness in a eutrophic reservoir (Barra Bonita Reservoir, SP, Brazil). Hydrobiologia, vol. 542, p. 367-378.

MATSUMURA-TUNDISI, T., NEUMANN-LEITÃO, S., AGUENA, L. and MIYAHARA, J., 1990. Eutrofização da represa de Barra Bonita: estrutura e organização da comunidade de Rotifera. Revista Brasileira de Biologia = Brazilian Journal of Biology, vol.50, p.923-935.

McCUNE, B. and MEFFORD, M. 1999. Multivariate Analysis of Ecological Data. Version 4.01. Oregon: MjM Software Design.

NOGUEIRA, M., 2001. Zooplankton composition, dominance and abundance as indicators of environmental compartmentalization in Jurumirim Reservoir Paranapanema River. São Paulo, Brazil. Hydrobiologia, vol.455, p.1-18.

PALAZZO, F., BONECKER, C.C. and FERNANDES, A.P.C., 2008. Resting cladoceran eggs and their contribution to zooplankton diversity in a lagoon of the Upper Paraná River floodplain. Lakes \& Reservoir: Research and Management, vol. 13, p. 207-214.

PENNAK, R., 1989. Fresh-water Invertebrates of the United States: Protozoa to Mollusca. New York: Wiley Interscience Publication.

PEJLER, B., 1983. Zooplankton indicators of trophy and their food. Hydrobiologia, vol.101, p.111-114.

PIMM, S., 1984. The complexity and stability of ecosystems. Nature, vol.307, p.321-326.

PIMM, S., 1991. The balance of nature? Ecological issues in the conservation of species and communities. Chicago: University of Chicago Press.

PINTO-COELHO, R.M., BEZERRA-NETO, J.F. and MORAISJr, C.A., 2005. Effects of eutrophication on size and biomass of crustacean zooplankton in a tropical reservoir. Brazilian Journal of Biology, vol. 65, p.325-338. 
REID, J.W., 1985. Chave de identificação e lista de referências bibliográficas para as espécies continentais de sulamericanas de vida livre da Ordem Cyclopoida Crustacea, Copepoda). Boletim de Zoologia, vol.9, p.17-143.

REJAS, D., DECLERCK, S., AUWERKERKEN, J., TAK, P. and MEESTER, L., 2005. Plankton dynamics in a tropical floodplain lake: fish, nutrients, and the relative importance of bottom-up and top-down control. Freshwater Biology, vol.50, p.52-69.

SANTOS, R., ROCHA, G., ROCHA, O. and WISNIEWSKI, M.J.S., 2009. Influence of net cage fish cultures on the diversity of the zooplankton community in the Furnas hydroelectric reservoir, Areado, MG, Brazil. Aquaculture Research, vol.40, p.753-761.

SCHMITTOU, H., 1993. High density fish culture in low volume cages. American Soybean Association, Singapore, vol.41, p.1993-1997.

SCHEFFER, M. and Van NES, E., 2007. Shallow lakes theory revisited: various alternative regimes driven by climate, nutrients, depth and lake size. Hydrobiologia, vol.584, p.455-466.

SCHEFFER, M., HOSPER, S.H., MEIJER, M-L., MOSS, B. and JEPPESEN, E., 1993. Alternative equilibria in shallow lakes. Tree, vol. 8, p. 275-279.

SILVA, W.M. and MATSUMURA-TUNDISI, T., 2002. Distribution and abundance of Cyclopoida populations in a cascade of reservoirs of the Tietê River São Paulo State, Brazil. Verhandlungen des Internationalen Verein Limnologie, vol.28, p.667-670.

TEIXEIRA, C., TUNDISI, J.G. and KUTNER, M.B., 1965. Plankton studies in a mangrove. II: The standing- stock and some ecological factors. Boletim do Instituto Oceanografico, vol.24, p.23-41.

TILMAN, D., WEDIN, D. and KNOPS, J., 1996. Productivity and sustainability influenced by biodiversity in grassland ecosystems. Nature, vol.379, p.718-720.

TUNDISI, J. G., 2003. Água no século XXI: Enfrentando a escassez. Rima, São Carlos.

VINEBROOKE, R., COTTINGHAM K., NORBERG, J., SCHEFFER, M., DODSON, S., MABERLY, S. and SOMMER, U., 2004. Impacts of multiple stressors on biodiversity and ecosystem functioning: the role of species co-tolerance. Oikos, vol.104, p.451-457.

WELLBORN, G., SKELLY, D. and WERNER, E., 1996. Mechanisms creating community structure across a freshwater habitat gradient. Annual Review of Ecology and Systematics, vol.27, p.337-363.

YIYONG, Z., JIANQIU, L., YONGQING, F. and MIN, Z., 2001. Kinetics of alkaline phosphatase in lake sediment associated with cage culture of Oreochromis niloticus. Aquaculture, vol.203, p.23-32. 
